\title{
Aktivitas Antibakteri Ekstrak Etanol Bunga Telang (Clitoria ternatea L.) Terhadap Bakteri Staphylococcus epidermidis
}

\author{
Fernanda Desmak Pertiwi ${ }^{1}$, Firman Rezaldi ${ }^{2}$, , Ranny Puspitasari ${ }^{3}$ \\ ${ }_{1,2,3}$ Program Studi S1 Farmasi Fakultas Sains Farmasi Kesehatan Universitas Mathla'ul Anwar Banten \\ ${ }^{*}$ Koresponden Penulis : firmanrezaldi417@gmail.com
}

\begin{abstract}
ABSTRAK
Bunga telang (Clitoria ternatea L.) merupakan salah satu tanaman yang telah lama digunakan dalam pengobatan dan telah terbukti memiliki aktivitas sebagai antibakteri. Penelitian ini bertujuan menguji aktivitas bunga telang yaitu dengan cara maserasi menggunakan pelarut etanol $70 \%$. Untukpengujian antibakteri dengan metode difusi disk. Ekstrak dibuat dalam berbagai konsentrasi 10\%, 15\%, 20\%. Kontrol positif yang digunakan adalah Chloramphenicol. Hasil dari penelitian ini yaitu rata-rata zona hambat ekstrak bunga telang terhadap bakteri Staphylococcus epidermidis 2,31 mm konsentrasi 10\%, 3,05 mm pada konsentrasi 15\%, dan 6,2 mm pada konsentrasi $20 \%$. Hasil tersebut menunjukkan bahwa ekstrak bunga telang mempunyai aktivitas antibakteri terhadap bakteri Staphylococcus epidermidis, meskipun daya hambat yang dihasilkan tidak kuat. Pada konsentrasi ekstrak bunga telang $20 \%$ mempunyai daya hambat paling besar terhadap pertumbuhan bakteri Staphylococcus epidermidis daripada konsentrasi $10 \%$ dan $15 \%$.
\end{abstract}

Kata kunci: bunga telang, antibakteri, Staphylococcus epidermidis.

\begin{abstract}
Telang flower (Clitoria ternatea L.) is a plant that has long been used in medicine and has been shown to have antibacterial activity. This study aims to test the activity of telang flower by maceration using $70 \%$ ethanol as solvent. For antibacterial testing with the disk diffusion method. Extracts are made in various concentrations of $10 \%, 15 \%, 20 \%$. The positive control used was Chloramphenicol. The results of this study were the average inhibition zone of telang flower extract against Staphylococcus epidermidis bacteria was $2.31 \mathrm{~mm}$ at a concentration of $10 \%, 3.05 \mathrm{~mm}$ at a concentration of $15 \%$, and $6.2 \mathrm{~mm}$ at a concentration of $20 \%$. These results indicate that the flower extract of telang has antibacterial activity against Staphylococcus epidermidis bacteria, although the inhibitory power produced is not strong. At a concentration of $20 \%$ telang flower extract had the greatest inhibition on the growth of Staphylococcus epidermidis bacteria than the 10\% and 15\% concentrations.
\end{abstract}

Keywords: antibacterial, Staphylococcus epidermidis, telang flower.

doi: $10.33474 /$ e-jbst.v7i2.471

Diterima tanggal 26 November 2021 - Diterbitkan Tanggal 29 Januari 2022

http://creativecommons.org/licenses/by/4.0 


\section{Pendahuluan}

Infeksi kulit masih menjadi suatu masalah kesehatan yang dihadapi masyarakat di negara berkembang termasuk Indonesia. Kulit (kutis) merupakan pembungkus dan pelindung tubuh yang tahan air, mengandung ujung-ujung saraf, dan membantu mengatur suhu tubuh [1].

Antibakteri merupakan zat yang dapat mengganggu pertumbuhan atau bahkan mematikan bakteri dengan cara mengganggu metabolisme mikroba yang merugikan. Mekanisme kerja dari senyawa antibakteri diantaranya yaitu menghambat sintesis dinding sel, menghambat keutuhan permeabilitas dinding sel bakteri, menghambat kerja enzim dan menghambat sintesis asam nukleatdan protein [2].

Salah satu tananman yang berkhasiat sebagai antibakteri yaitu bunga C.teantea L. karena mengandung metabolit sekunder flavonoid dan alkaloid yang berpotensi sebagai antibakteri [3]. Mahmad et al (2018) melaporkan bahwa ekstral etanol bunga C.tenatea L. mampu menghambat pertumbuhan beberapa jenis bakteri yaitu Bacillus subtilis, Staphylococcus aureus dan Escherichia coli [4] [5] . Penelitian sebelumnya yang telah dilakukan oleh Hidayah (2015) terhadap aktivitas antibakteri ekstrak etanol bunga telang dan ekstrak etanol daun sirsak termasuk kategori kuat terhadap bakteri Staphylococcus aureus dan bakteri Staphylococcus epidermidis. Secara umum, methanol dan etanol adalah pelarut yang terbaik untuk ekstraksi komponen fitokimia bunga C.tenatea L. sebagai antibakteri $[6]$.

Bakteri Staphylococcus epidermidis merupakan flora normal pada kulit manusia dan pada umunya, tidak mempunyai masalah bagi orang normal yang sehat. Akan tetapi, organisme ini menjadi patogen oportunis yang menyebabkan nosokominal pada persendian dan pembuluh darah. Menurut Darojah (2019) bakteri Staphylococcus epidermidis memiliki pravelensi infeksi nosokomial pada luka operasi sebesar $40 \%$. Infeksi ini terjadi apabila luka paska operasi terkontaminasi oleh bakteri ini sehingga berkembang biak secara leluasa tanpa hambatan, populasi menjadi besar mengakibatkan peningkatan jumalah yang hidup didalam tubuh. [7]

\section{Material dan Metode}

\section{Alat dan Bahan}

Peralatan yang digunakan dalam penelitian ini yaitu inkubator, blender, timbangan analitik, rotary evaporasi, autoklaf, lemari aseptis, alat gelas laboratorium, hot plate, eppendrof tube, botol steril, jangka sorong, kaki tiga, spirtus, cawan petri, cotton bud, tips mikropipet, mikropipet, jarum ose, kain kasa steril, kapas steil, handscoon, dan kertas label.

Bahan yang digunakan dalam peneltian ini yaitu ekstrak etanol bunga telang (Clitoria ternatea L.), bakteri Staphylococcus epidermidis, etanol 70\%, akuades, DMSO (dimethyl sulfoxide), Chloramphenicol, Nutrient agar (NA), Muller Hiton Agar (MHA), alumunium foil.

\section{Metode}

Jenis penelitian ini adalah penelitian eksperimental yang dilakukan secara in vitro. Penelitian akan dilaksanakan pada bulan Agustus-September 2021 di Laboratorium UPTD Pengujian dan Penerapan Mutu Hasil Perikanan (PPMHP) provinsi Banten. 


\section{Cara Kerja}

Penelitian ini dilakukan dalam beberapa tahapan kegiatan, yaitu proses determinasi bunga C.ternatea L., pengambilan dan preparasi bunga C.ternatea L., pembuatan ekstrak etanol bunga C.ternatea L., uji fitokimia bunga C.ternatea L., uji ekstrak kental bunga C.ternatea L. terhadap bakteri, formulasi sediaan liq body wash ekstrak etanol bunga C.ternatea L., evaluasi sediaan liq bodywash ekstrak etanol bunga C.ternatea L., uji aktivitas sediaan liq body wash ekstrak etanol bunga C.ternatea L. terhadap bakteri Staphylococcus epidermidis.

\section{Hasil Penelitian}

\section{Hasil Determinasi}

Determinasi tanaman bertujuan untuk mencocokan ciri-ciri morfologi yang ada pada tanaman yang akan diteliti agar tidak terjadi kesalahan dalam mengambil tanaman untuk penelitian. Berdasarkan hasil determinasi menunjukkan bahwa sampel yang digunakan dalam penelitian ini adalah Bunga Telang (Clitoria ternatea L.) dengan suku Fabaceae / Leguminosae. Hasil determinasi bunga telang (Tabel 4.1).

Tabel 4.1 Hasil Determinasi

\begin{tabular}{ccc}
\hline Sampel & Jenis & Suku \\
\hline Bunga Telang & Clitoria ternatea L. & Fabaceae / Leguminosae \\
\hline
\end{tabular}

\section{Simplisia Dan Ekstrak Bunga C.ternatea L.}

Pembuatan simplisia dilakukan dengan cara melalui beberapa tahap persiapan diantaranya pengambilan bunga telang segar, sortasi basah, pencucian, pengeringan, sortasi kering dan penghalusan simplisia. Hasil pembuatan simplisia bunga telang (C.ternatea) (Tabel 4.2).

Tabel 4.2 Hasil Pembuatan Simplisia

\begin{tabular}{ccc}
$\begin{array}{c}\text { Bunga Segar } \\
(\mathrm{g})\end{array}$ & $\begin{array}{c}\text { Bunga Kering } \\
(\mathrm{g})\end{array}$ & $\begin{array}{c}\text { Serbuk Kering } \\
(\mathrm{g})\end{array}$ \\
\hline 10.000 & 1.200 & 1.000 \\
\hline
\end{tabular}

Proses ekstraksi pada penelitian ini menggunakan metode maserasi. Dalam bahasa latin maserasi artinya merendam. Maserasi merupakan metode penyarian zat aktif menggunakan pelarut yang sesuai dengan pengadukan yang dilakukan beberapa kali pada suhu kamar selama periode waktu tertentu. Maserasi termasuk kedalam metode cara dingin yang dapat melindungi senyawa metabolit sekunder yang tidak tahan terhadap pemanasan salah satunya adalah flavonoid [9]. Pelarut yang digunakan dalam pembuatan ekstrak ini yaitu etanol 70\%. Pemilihan etanol 70\% dikarenakan memiliki kemampuan penetrasi yang baik pada sisi hidrofil dan lipofil, sehingga dapat menembus membran sel lalu dapat masuk ke dalam sel dan berinteraksi dalam metabolit yang terdapat dalam sel. Etanol 70\% juga mampu mengambil senyawa yang diperlukan seperti flavonoid, alkaloid, tanin, terpenoid dan saponin pada bunga C.ternatea L. [10]. Ekstrak kental yang diperoleh sebanyak 94,5g dengan rendemen 9,45\% (Tabel 4.3).

.Tabel 4.3 Hasil Ekstrak Kental Etanol Bunga C.ternatea L.

\begin{tabular}{ccccc}
$\begin{array}{c}\text { Serbuk Kering } \\
(\mathrm{g})\end{array}$ & $\begin{array}{c}\text { Etanol 70\% } \\
(\mathrm{ml})\end{array}$ & $\begin{array}{c}\text { Ekstrak Cair } \\
(\mathrm{ml})\end{array}$ & $\begin{array}{c}\text { Ekstrak Kental } \\
(\mathrm{g})\end{array}$ & $\begin{array}{c}\text { Rendemen } \\
(\%)\end{array}$ \\
\hline
\end{tabular}


e-Jurnal Ilmiah BIOSAINTROPIS (BIOSCIENCE-TROPIC)

Volume 7/ No.: 2 / Halaman 57 - 68 / Januari Tahun 2022

ISSN : 2460-9455(e) - 2338-2805(p) 


\section{Hasil Uji Fitokimia}

Uji skrining fitokimia bertujuan untuk menentukan kandungan metabolit skunder yang terdapat pada ekstrak etanol bunga telang. Uji skrining fitokimia yang akan dilakukan meliputi uji alkaloid, flavonoid, tanin, saponin, terpenoid/steroid.

\section{Pemeriksaan Flavonoid}

Sebanyak 0,5 g sampel ditambahkan $2 \mathrm{~mL}$ methanol 50\%. Dipanasakan pada suhu $50^{\circ} \mathrm{C}$ kemudian didinginkan. Ditambahkan logam magnesium, ditambahkan 5 tetes asam klorida pekat. Jika timbul warna merah/jingga maka positif mengandung flavonoid [11].

\section{Pemeriksaan Tanin}

Sebanyak 0,5 g sampel dimasukan kedalam tabung reaksi tambahkan $5 \mathrm{~mL}$ akuades lalu dicampurkan dengan 2 tetes larutan $\mathrm{FeCl}_{3} 1 \%$, jika larutan menunjukan warna biru tua atau hitam kehijauan menandakan adanya tanin dan polifenol [12].

\section{Pemeriksaan Saponin}

Sebanyak 0,5 g sampel dimasukan kedalam tabung reaksi tambahkan $9 \mathrm{~mL}$ akuades, kemudian dipanaskan selama 3-5 menit, dinginkan dan kocok kuat lalu tambah 2 tetes $\mathrm{HCl} 2 \mathrm{~N}$ hingga terbentuk busa yang permanen (busa tidak hilang selama 7 menit) menandakan adanya saponin [13].

\section{Pemeriksaan Alkaloid}

Sebanyak $0,5 \mathrm{~g}$ sampel ditambahkan akuades $9 \mathrm{~mL}$ dan $\mathrm{HCl} 2 \mathrm{~N}$, dipanaskan pada penangas air selama 2 menit. Setelah dingin filtrat diambil sebanyak 3 tetes untuk ditambahkan kedalam reagen yang sudah disiapkan. Reagen Mayer akan membentuk endapan putih jika positif mengandung alkaloid, lalu reagen Wegner akan menghasilkan endapan coklat jika positif mengandung alkaloid. Kemudian reagen Dragendroff akan menghasilkan endapan jingga atau merah jika positif menghasilakn alkaloid [14].

\section{Pemeriksaan Steroid/Terpenoid}

Sebanyak 0,5 g sampel masukan kedalam tabung reaksi, kemudian filtrat dilarutkan dengan $0,5 \mathrm{~mL}$ kloroform dan tambahkan $0,5 \mathrm{~mL}$ asam asetat anhidrat, selanjutnya tambahkan $\mathrm{H}_{2} \mathrm{SO}_{4}$ pekat melalui dinding tabung. Jika menunjukkan warna kecoklatan atau violet pada perbatasan larutan akan menandakan adanya terpenoid, sedangkan bila menunjukkan warna biru kehijauan menandakan adanya steroid [15].

Tabel 4.4 Uji Skrining Fitokimia

\begin{tabular}{lll}
\hline Senyawa Metabolit & Hasil & Keterangan \\
\hline Alkaloid & Positif alkaloid, pada reagen meyer \\
\hline
\end{tabular}


e-Jurnal Ilmiah BIOSAINTROPIS (BIOSCIENCE-TROPIC)

Volume 7/ No.: 2 / Halaman 57 - 68 / Januari Tahun 2022

ISSN : 2460-9455(e) - 2338-2805(p)

Flavonoid

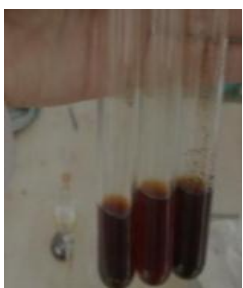

Positif flavonoid

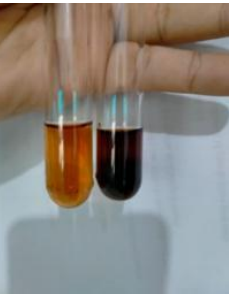

Positif tanin

Tanin

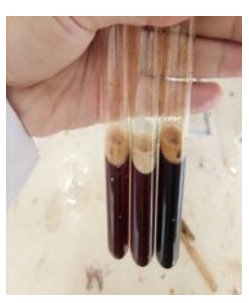

Positif saponin

Saponin
Positif saponin

\begin{tabular}{lll} 
Tanin & Positif tanin \\
\hline Saponin & \\
\hline Terpenoid & Positif saponin \\
\hline
\end{tabular}




\section{Hasil Uji Antibakteri}

Pengujian antibakteri ekstrak etanol bunga C.ternatea L. dilakukan dengan menggunakan metode difusi cakram. Hal ini untuk mengetahui ada tidaknya pengaruh ekstrak etanol bunga C.ternatea L. dalam menghambat pertumbuhan bakteri S.epidermidis. Media agar yang digunakan dalam penelitian ini adalah media Muller Hinton Agar (MHA) karena media ini telah terbukti memberikan hasil yang baik. Media Muller Hinton Agar (MHA) mempunyai kandungan pepton kasein, pati dimana Muller Hinton adalah media uji sensitivitas antibiotik untuk bakteri-bakteri yang mudah tumbuh seperti bakteri S.epidermidis [16]. Pada pembuatan media agar miring digunakan media Muller Hinton Agar (MHA). Bakteri S.epidermidis ditumbuhkan pada media agar miring Muller Hinton Agar (MHA) yang selanjutnya digunakan untuk pembuatan suspensi bakteri. Bakteri diinokulasi pada media agar Muller Hinton Agar (MHA). Pengujian aktivitas antibakteri S.epidermidis terhadap ekstrak etanol bunga C.ternatea L. dilakukan dengan tiga konsentrasi yaitu konsentrasi $10 \%$, konsentrasi $15 \%$, dan konsentrasi $20 \%$ dengan dua kontrol sebagai pembanding yaitu kontrol positif menggunakan Chloramphenicol karena termasuk dalam golongan antibiotik berspektrum luas yang mampu menghambat pertumbuhan bakteri Gram positif dan Gram negatif. Hasil pengujian aktivitas antibakteri (Gambar 4.1) dan hasil pengukuruan zona hambat (Tabel 4.5) sebagai berikut:

Tabel 4.5 Hasil Pengukuran Diameter Zona Hambat (mm) Ekstrak Etanol Bunga C.ternatea L. Terhadap Pertumbuhan Bakteri S.epidermidis.

\begin{tabular}{|c|c|c|c|c|c|c|}
\hline \multicolumn{7}{|c|}{ Diameter Zona Hambat (mm) } \\
\hline No & Konsentrasi & $\mathbf{I}$ & II & III & $\begin{array}{c}\text { Rata-rata } \\
\text { zona } \\
\text { hambat } \\
(\mathbf{m m})\end{array}$ & Kategori \\
\hline 1 & $\begin{array}{l}\text { kontrol (-) } \\
\text { DMSO }\end{array}$ & 0 & 0 & 0 & 0 & \\
\hline 2 & $\begin{array}{l}\text { kontrol (+) } \\
\text { Chlroamphenicol }\end{array}$ & 8,55 & 8,70 & 8,00 & 8,41 & Sedang \\
\hline 3 & $10 \%$ & 1,45 & 2,65 & 2,85 & 2,31 & Lemah \\
\hline 4 & $15 \%$ & 2,80 & 3,25 & 3,10 & 3,05 & Lemah \\
\hline 5 & $20 \%$ & 6,20 & 6,50 & 5,90 & 6,20 & Sedang \\
\hline
\end{tabular}

\section{Pembahasan}

\section{Hasil Detereminasi}

Determinasi merupakan proses yang dilakukan untuk mengetahui kebenaran asal dari simplisia yang digunakan dalam penelitian sebelum dilakukan penelitian. Bagian tanaman yang digunakan pada penelitian ini adalah bagian bunga telang (Clitoria ternatea L.), yang diperoleh dari daerah Cibaliung Banten. Determinasi bunga C.ternatea dilakukan di Herbarium Bogoriense Bidang Botani Pusat Penelitian Biologi Lembaga Ilmu Pengetahuan Indonesia (LIPI) menyatakan bahwa hasil identifikasi sampel atau bahan yang digunakan dalam penelitian dengan nomor surat 
B-573/IV/DI.01/5/2021 adalah benar tanaman telang dengan nama latin Clitoria ternatea L.dengan suku Fabaceae/Leguminosae.

\section{Hasil Simplisia Dan Ekstrak Bunga C.ternatea L.}

Simplisia adalah bahan alamiah yang digunakan sebagai obat yang belum mengalami pengolahan apapun juga, kecuali dinyatakan lain, berupa bahan yang telah dikeringkan. Pembuatan simplisia bunga C.ternatea L. yaitu dimulai dengan mengumpulkan sampel bunga C.ternatea L. varietas ungu sebangak $10.000 \mathrm{~g}$, selanjutnya dilakukan sortasi basah untuk memilah bunga C.ternatea L. segar yang masih utuh dan menghilangkan benda asing yangterdapat pada bunga C.ternatea $\mathrm{L}$. bahan hasil sortasi basah tadi dicuci menggunakan air mengalir untuk menghilangkan kotoran yang menempel pada bunga C.ternatea L. dan ditiriskan, kemudianbunga yang ditiriskan tadi dihamparkan diatas nampan / wadah untuk dikeringkan dibawah sinar matahari langsung dan ditutupi dengan kain hitam bertujuan agar senyawa aktif dalam sampel tidak mengalami kerusakan, mengurangi kadar air, menghentikan reaksi enzimatis, dan mencegah tumbuhnya jamur sehingga dapat disimpan lama (pengawetan) [17].

Bunga yang telah kering disortasi kering untuk memisahkan benda-benda asing yang tercampur pada saat proses pengeringan. Kemudian sampel yang telah kering ditimbang dan diperoleh sebanyak $1.200 \mathrm{~g}$. Setelah itu sampel kering dihaluskan menggunakan blender. Penghalusan bertujuan untuk merusak sel serta memperluas permukaan sampel yang akan diekstrak. Serbuk yang halus kemungkinan sel-sel yang rusak juga semakin besar, sehingga memudahkan penarikan bahan kandungan langsung oleh pelarut. Semakin kecil ukurannya, semakin besar luas permukaannya maka interaksi zat cair ekstraksi akan semakin besar, sehingga proses ekstraksi akan semakin efektif, serbuk halus bunga C.ternatea L. diayak dengan mesh 60, ditimbang dan diperoleh sebanyak $1.000 \mathrm{~g}$.

Proses ekstraksi pada penelitian ini menggunakan metode maserasi. Dalam bahasa latin maserasi artinya merendam. Maserasi merupakan metode penyarian zat aktif menggunakan pelarut yang sesuai dengan pengadukan yang dilakukan beberapa kali pada suhu kamar selama periode waktu tertentu. Maserasi termasuk kedalam metode cara dingin yang dapat melindungi senyawa metabolit sekunder yang tidak tahan terhadap pemanasan salah satunya adalah flavonoid [18]. Pelarut yang digunakan dalam pembuatan ekstrak ini yaitu etanol $70 \%$. Pemilihan etanol $70 \%$ dikarenakan memiliki kemampuan penetrasi yang baik pada sisi hidrofil dan lipofil, sehingga dapat menembus membran sel lalu dapat masuk ke dalam sel dan berinteraksi dalam metabolit yang terdapat dalam sel. Etanol $70 \%$ juga mampu mengambil senyawa yang diperlukanseperti flavonoid, alkaloid, terpenoid dan steroid pada bunga C.ternatea $\mathrm{L}$ [19].

Ekstraksi dilakukan selama tiga hari dengan cara merendam $1.000 \mathrm{~g}$ serbuk bunga C.ternatea L. dalam $5.000 \mathrm{ml}$ etanol 70\% diamkan selama 1x24 jam, aduk setiap 2-3 jam sekali. Setelah itu disaring dan simpan filtratnya kedalam wadah tertutup. Kemudian ampasnya digunakan kembali untuk melakukan proses remaserasi dalam $1.500 \mathrm{ml}$ etanol $70 \%$ tujuannya untuk menyari kembali kandungan kimia yang mungkin masih tertinggal didalam ampas karena pelarut pertama sudah mengalami kejenuhan, diamkan selama 1x24 jam dan saring. Lakukan remaserasi dengan cara yang sama seperti hari kedua. Filtrat dikumpulkan kedalam satu wadah, timbang dan diperoleh sebanyak $4.970 \mathrm{ml}$ ekstrak cair.

Untuk memperoleh ekstrak kental yaitu dengan melakukan penguapan ekstrak cair yang sudah didapatkan menggunakan rotary evaporator pada suhu $55^{\circ} \mathrm{C}$ dengan putaran $80 \mathrm{rpm}$, kelebihan dalam alat ini yaitu efektif dalam menguapkan solven namun tidak merusakan senyawasenyawa yang terkandung didalam bunga C.ternatea L. Hasil ekstraksi yang diperoleh rendemen sebesar $9,45 \%$ yang artinya dari $1.000 \mathrm{~g}$ serbuk simplisia bunga C.ternatea L. dengan ekstraksi metode maserasi menggunakan pelarut etanol 70\% didapat ekstrak kental sebanyak 94,5g. 


\section{Hasil Uji Fitokimia}

Hasil skrining fitokimia bunga C.ternatea L. memberikan hasil positif flavonoid, tanin, saponin, alkaloid dan terpenoid, hasil ini sesuai dengan penelitian yang dilakukan oleh [20].

\section{Hasil Uji Antibakteri}

Pengujian antibakteri pada ekstrak etanol bunga C.ternatea L. terbukti bahwa ekstrak etanol bunga C.ternatea L. memiliki kemampuan antibakteri yang menghasilkan zona hambat terhadap bakteri S.epidermidis dengan metode cakram. Penggunaan metode ini karena metode difusi merupakan metode umum yang praktis serta mudah dalam pengujian, kepekaan antibakteri terhadap bakteri aerob maupun bakteri fakultatif anaerob, cepat dalam pembacaan hasil, sehingga cocok untuk digunakan dalam penelitian. Media agar yang digunakan dalam penelitian ini adalah media Muller Hinton Agar (MHA) karena media ini telah terbukti memberikan hasil yang baik. Media Muller Hinton Agar (MHA) mempunyai kandungan pepton kasein, pati dimana Muller Hinton adalah media uji sensitivitas antibiotik untuk bakteri-bakteri yang mudah tumbuh seperti bakteri Staphylococcus epidermidis [21].Pada pembuatan media agar miring digunakan media MHA. Bakteri S.epidermidis ditumbuhkan pada media agar miring Muller Hinton Agar (MHA) yang selanjutnya digunakan untuk pembuatan suspensi bakteri. Bakteri diinokulasi pada media agar MHA. Pengujian aktivitas antibakteri S.epidermidis terhadapekstrak etanol bunga C.ternatea L. dilakukan dengan tiga konsentrasi yaitu konsentrasi 10\%, konsentrasi 15\%, dan konsentrasi $20 \%$ dengan dua kontrol sebagai pembanding yaitu kontrol positif menggunakan chloramphenicol karena termasuk dalam golongan antibiotik berspektrum luas yang mampu menghambat pertumbuhan bakteri Gram positif dan Gram negatif. Mekanisme dari chloramphenicol yaitu, menghambat sintesis protein, mencegah ujung amino asil t-RNA bergabung dengan peptidil transferase, sedangkan kontrol negatif yang digunakan dalam penelitian ini adalah DMSO karena dapat melarutkan senyawa polar dan nonpolar serta tidak akan mengganggu hasil pengamatan karena DMSO tidak memberikan aktivitas terhadap pertumbuhan bakteri.

Pengujian hasil uji bakteri ekstrak etanol bunga C.ternatea $\mathrm{L}$. diperoleh zona hambat pada konsentrasi $10 \%$ adalah 2,31 mm, konsentrasi $15 \%$ adalah 3,05 mm, dan pada konsentrasi $20 \%$ adalah $6,20 \mathrm{~mm}$, dimana konsentrasi $10 \%$ dan $15 \%$ memiliki zona hambat dalam kategori lemah dan untuk konsentrasi $20 \%$ memiliki zona hambat dalam kategori sedang. Hasil diameter pada kontrol positif (chloramphenicol) memberikan diameter zona hambat dengan rata-rata adalah 8,41 $\mathrm{mm}$, sedangkan pada kontrol negatif (DMSO) tidak menghasilkan zona hambat. Terbentuknya area bening di sekitar cakram pada uji aktivitas antibakteri membuktikan bahwa pertumbuhan bakteri yang berada dalam media agar terhambat.

Keberadaan metabolit sekunder dalam ekstrak menjadi faktor yang penting dalam menghambat pertumbuhan bakteri. Metabolit sekunder yang terkandung dalam bunga C.ternatea L. adalah alkaloid, flavonoid, tannin, saponin dan terpenoid. Mekanisme kerja alkaloid sebagai antibakteri yaitu dengan cara menghambat komponen penyusun peptidoglikan pada sel bakteri, sehingga dinding sel tidak terbentuk utuh. Hal tersebut menyebabkan kematian sel [22]. Mekanisme flavonoid sebagai antibakteri adalah membentuk senyawa kompleks dengan protein ekstraseluler dan terlarut yang mengakibatkan fospolipid tidak mampu mempertahankan bentuk membran sel bakteri, akibatnya membran sel bakteri akan menjadi bocor dan bakteri mengalami hambatan pertumbuhan bahkan kematian. Mekanisme tanin sebagai antibakteri adalah mengganggu sintesa peptidoglikan sehingga pembentukan dinding sel menjadi kurang sempurna. Keadaan tersebut menyebabkan keadaan sel menjadi lisis karena tekanan osmotik maupun fisik sehingga sel bakteri menjadi mati. Mekanisme saponion sebagai antibakteri adalah menurunkan tegangan permukaan dinding sel bakteri, sehingga mengakibatkan naiknya permeabilitas atau kebocoran sel dan mengakibatkan senyawa intraseluler akan keluar [23].Mekanisme terpenoid sebagai antibakteri yaitu dengan cara merusak membran [24].

Data penelitian yang didapat dilakukan uji statistik berupa uji One Way ANOVA. One way ANOVA merupakan metode parametik dalam uji perbandingan yang dapat digunakan apabila ingin membandingkan rataan dua atau lebih populasi yang saling bebas. Sebelum dilakukan uji tersebut maka harus dilakukan uji normalitas untuk memastikan data terdistribusi normal dan uji varians 

menggunakan uji One Way ANOVA. Berdasarkan uji normalistas, data zona hambat yang diuji berdistribusi normal. Hal ini dibuktikan pada ektrak etanol bunga C.ternatea L. memiliki nilai signifikan > 0,05, sehingga terbukti bahwa data terdistribusi normal. Selanjutnya dilakukan uji homogenitas, syarat dari uji One Way ANOVA yaitu varians antar kelompok harus homogen. Berdasarkan uji homogenitas data yang diperoleh ternyata tidak memiliki varians yang tidak sama karena nilai signifikan 0,017 $<0,05$ sehingga terbukti bahwa data tidak homogen. Karena data yang diperoleh tidak memenuhi persyaratan dari One Way ANOVA maka ektrask etanol bunga C.ternatea L. tidak bisa dilanjutkan dengan uji ANOVA.

\section{Kesimpulan}

Berdasarkan hasil penelitian maka dapat disimpulkan bahwa ekstrak etanol bunga C.terantea L. kemampuan menghambat pertumbuhan terhadap bakteri Staphylococcus epidermidis pada konsentrasi $10 \%, 15 \%$ dan 20\%. Hasil uji aktivitas antibakteri ekstrak etanol bunga C.terantea L. pada konsentrasi $10 \%$ dan $15 \%$ masuk dalam kategori lemah karena menghasilkan rata-rata diameter zona hamabat sebesar 2,31 $\mathrm{mm}$ dan 3,05 mm, sedangkan konsentrasi $20 \%$ masuk dalam kategori sedang dengan rata-rata diameter zona hambat $6,2 \mathrm{~mm}$.

\section{Daftar Pustaka}

[1] Gardner, Gray, O’rahilly, 1995. Anatomi. Penerbit Universitas Indonesia, Jakarta.

[2] Dwidjoseputro, D., 1978. Dasar-dasar mikrobiologi. Jakarta.

[3] Budiasih KS. 2017. Kajian potensi farmakologis bunga telang (Clitoria ternatea L.). Dalam: Sinergi penelitian dan pembelajaran untuk mendukung pengembangan literasi kimia pada era global. Prosiding Seminar Nasional Kimia. Yogyakarta (Indonesia). hal. 201-206.

[4] Mahmad, N., Taha, R. M., Othman, R., Abdullah, S., Anuar, N., Elias, H., \& Rawi, N. 2018. Anthocyanin as potential source for antimicrobial activity in Clitoria ternatea L. and Dioscorea alata L. Pigment \& Resin Technology, 47(6): 490-495.

[5] Kamilla L, Mnsor S.M, Ramanathan S \& Sasidharan S. 2009. Antimicrobial Activity of Clitoria ternatea L. Extracts. Pharmacologyonline, 1: 731-738.

[6] Hidayah, S. N. 2015. Uji Aktivitas Antibakteri Kombinasi Ekstrak Etanol Bunga Telang (Clitoria ternatea L.) Dan Ekstrak Etanol Daun Sirsak (Annona muricata L.) Terhadap Staphylococcus aureus Dan Staphylococcus epidermidis. Surakarta: Universitas Sebelas Maret. [5] Environmental Ministry of Republic of Indonesia. 2008. Perface of International Seminar of Integrated Waste Management, Science and Technology. Jakarta. 50 hal.

[7] Darojah, P., Santoso, O. dan Ciptaningtyas, V. R. 2019. Pengaruh Asap Cair Berbagai Konsentrasi Terhadap Viabilita Staphylococcus epidermidis. Disertasi. Fakultas KedokteranUniversitas Airlangga.

[8] Silvia, Arreneuz, S., \& Wibowo, M. A. 2015. Aktivitas Antimikroba Ekstrak Daun Soma (Ploarium alternifolium Melch) Terhadap Jamur Mallasezia furfur dan Bakteri Staphylococcus aureus. Jurnal Kimia dan Kemasan. 4 : 84-93.

[9] Anggraini, I. D. dan Kusuma, W. E. 2019. Uji Potensi Fraksi Etil Asetat Buah Apel Hijau (Pyrus malus L.) Terhadap Penurunan Kadar Kolesterol Secara In Vitro. Journal Ilmiah Cendikia Eksakta, $7-14$. 
e-Jurnal Ilmiah BIOSAINTROPIS (BIOSCIENCE-TROPIC)

Volume 7/ No.: 2 / Halaman 57 - 68 / Januari Tahun 2022

ISSN : 2460-9455 (e) - 2338-2805(p)

[10] Andriani, D., \& Murtisiwi, L. (2018). Penetapan Kadar Fenolik Total Ekstrak Etanol Bunga Telang (Clitoria ternatea L.) Dengan Spektrofotometri UV Vis. Cendekia Journal of Pharmacy, 2(1), 32-38.

[11] Ningsih, I, Y. 2016. Penanganan Pasca Panen. Jember: Universitas Jember.

[12] Wijaya, D. P., Jessy E., Paendong, \& Jemmy A. 2014. Skrining fitokimia dan Uji Aktivitas Antioksidan dari daun nasi (Phrynium capitatum) dengan metode DPPH (1,1-difenil-2pikrilhidrazil). Jurnal MIPA 3(1): 11-15.

[13] Wijaya, D. P., Jessy E., Paendong, \& Jemmy A. 2014. Skrining fitokimia dan Uji Aktivitas Antioksidan dari daun nasi (Phrynium capitatum) dengan metode DPPH (1,1-difenil2-pikrilhidrazil). Jurnal MIPA 3(1): 11-15.

[14] Mondong, F, R., Sangi, M, E., \& Kumaunang, M. 2015. Skrining Fitokimia dan Uji Aktivitas Antioksidan Ekstrak Etanol Daun Patikala Emas (Euprorbia prunifolia Jacq.) dan Bawang Laut (Proiphys amboinensis (L.) Herb). Jurnal MIPA UNSRAT. 4(1):81-87. 
[15] Puspitasari, A. D., \& Proyogo, L. S. 2013. Perbandingan Metode Ekstraksi Maserasi dan Sokletasi Terhadap Kadar Fenolik Total Ekstrak Etanol Daun Kersen (Muntingia calabura). Jurnal Ilmiah Cendekia Eksakta. 1-8.

[16] Apriana, R., Rahmawanty, D., \& Fitriana, M . 2017. Formulasi dan Uji Stabilitas Gel Antijerawat yang Mengandung Kuarsetin serta Uji Efektifitas Terhadap Staphylococcus epidermidis. Jurnal Pharmascience, 4(2): 187-201.

[17] Putra, A. H., \& Rahayu, Y. C. (2017). Uji Aktivitas Antibakteri Ekstrak Etanol Daun Kamboja Putih (Plumeria acuminata) Terhadap Pertumbuhan Streptococcus mutans (Antibacterial Activity Of Etanol Extract Of White Frangipani leaf (Plumeria acuminata) Against The Growth Of Streptococcus mutan. Pustaka Kesehatan, 5(3), 449-453.

[18] Handayani, Fitriani., Warnida Husnul., \& Nur Juhairah Siti. 2016. Formulasi dan Uji Aktivitas Antibakteri Streptococus mutans Dari Sediaan Mouthwash Esktrak Daun Salam. Media Sains. Vol 9(1). 74-84.

[19] Malanggi, L.P., Meiske S.S. \& Jessy J.E.P. 2012. Penentuan kandungan tannin dan uji aktivitas antioksidan ekstrak biji buah alpukat (Persea americana Mill.). Jurnal MIPA Unsrat, 1:5- 10.

[20] Cahyaningsih, E., Yuda, P. E. S. K., \& Santoso, P. 2019. Skrining Fitokimia Dan Uji Aktivitas Antioksidan Ekstrak Etanol Bunga Telang (Clitoria ternatea L.) Dengan Metode Spektrofotometri UV-VIS. Jurnal Ilmiah Medicamento, 5(1): 51-57.

[21] Korompis, F. C., Yamlean, P. V., \& Lolo, W. A., 2020. Formulasi dan uji efektivitas antibakteri sediaan sabun cair ekstrak etanol daun kersen (Muntingia Calabura L.) terhadap bakteri Staphlococcous epidermidis. Pharmacon Jurnal Ilmiah Farmasi - UNSRAT. 9(1): 30-37.

[22] Riyanto, E. F., Nurjanah, A. N., Ismi, S. N., \& Suhartati, R. 2019. Daya Hambat Ekstrak Etanol Bunga Telang (Clitoria Ternatea L) Terhadap Bakteri Perusak Pangan. Jurnal Kesehatan, $19,218-225$.

[23] Malanggi, L. P., Meiske, S. S. \& Jessy J. E. P. 2012. Penentuan kandungan tanin dan uji aktivitas antioksidan ekstrak biji buah alpukat (Persea americana Mill). Jurnal MIPA UNSRAT, 1: $5-10$. 